\title{
The pecking order of innovation finance
}

\author{
Andrea Mina \\ Sant'Anna School of Advanced Studies, Piazza Martiri della Libertà, 33, 56127 Pisa, Italy \\ and Cambridge Judge Business School, University of Cambridge, Trumpington Street, \\ Cambridge, CB2 1AG, UK, andrea.mina@santannapisa.it, +39050883288 \\ Henry Lahr \\ Centre for Business Research, University of Cambridge, Trumpington Street, Cambridge, \\ CB2 1AG, and Department of Accounting and Finance, The Open University, The Open \\ University Business School, Walton Hall, Milton Keynes, MK7 6AA, UK, \\ h.lahr@cbr.cam.ac.uk, +44 1908332648
}

August 2018

\begin{abstract}
This paper examines the relationship between firms' innovation activities and the hierarchy of financing behaviours. We analyse the role of innovation inputs (R\&D), intermediate outputs (patents) and outcomes (product and process innovations) as sources of information asymmetry in financing decisions. Our focus on mainly unlisted companies allows us to study the effects of information asymmetries in the context where they are most severe, that is, among small and medium sized firms. We identify the effect of innovation, alongside the size of the firm, its age and its human capital, on the order of directly observed external capital allocations. Our results show that innovation is negatively associated with the standard pecking order of increasing agency costs, and that the more uncertain the innovation signal, the stronger its effect on the pecking order.
\end{abstract}

Keywords: R\&D, innovation, information asymmetries, capital structure, pecking order.

JEL Classification: G32, O16, O30 


\section{Introduction}

The ability to access financial resources is a key enabler of entrepreneurship and firm growth. However, financial market imperfections can lead to misallocation of capital and underexploitation of investment opportunities. Departures from optimality conditions are generally ascribed to information asymmetries and adverse selection which arise in the investment process when potential borrowers do not send reliable signals about their quality or when investors cannot capture these signals (Stiglitz and Weiss, 1981; Jensen and Meckling, 1976).

The nature and scope of financial market imperfections vary together with the form of capital that is supplied and with the agents' ability to bridge information gaps. The pecking order theory of corporate finance posits that firms will access additional capital according to a specific order of preferences: first of all, other things being equal, they will prefer internal to external finance, and secondly they will favour debt over equity (Myers, 2000; Myers and Majluf, 1984). ${ }^{1}$ Firms have informational advantages over external agents when investment risk does not arise from observable sources such as the market or currencies, but is instead idiosyncratic to the firm. This reduces the transparency of the company as an investment opportunity and increases the agency cost of outside finance to compensate for higher risks. Institutional differences between alternative sources of external capital reflect different propensities to risk as well as different information-processing abilities. ${ }^{2}$

Among the factors that can influence the pecking order, firm heterogeneity due to innovation poses an interesting challenge (Dosi, 1988). Innovative firms can be valuable investment opportunities, but are also riskier for investors 1) because they typically undertake

\footnotetext{
${ }^{1}$ The link between information asymmetries and forms of capital has been studied in the context of banks (among others, Berger et al., 2001; Berger and Udell, 1998; 2006), lease and supplier finance (Tamari, 1970; Myers et al., 1976; Porter, 1995), venture capital finance (Gompers and Lerner, 1999, 2001), angel finance (Goldfarb et al., 2013; Wong et al., 2009; Harrison and Mason, 2000). However, despite the growing emphasis on pecking order models, very few studies take into account simultaneously a broad spectrum of external finance allocation decisions.

${ }^{2}$ For a recent review of pecking order and alternative theories of capital structure see Frank and Goyal (2008).
} 
research and development activities of uncertain outcomes (technology risk), 2) because full disclosure of information on innovation projects can prevent the protection of imitable intangible assets (value appropriation risk) and 3) because the achievement of R\&D targets does not guarantee success in the market place (market risk). Firms may find it prohibitively expensive to reveal information about intended and potential outcomes of these investment opportunities to suppliers of external finance (Hall, 2010). In addition, investors will be aware of the increased risks of moral hazard and expropriation by incumbents induced by asymmetric information. External finance is therefore provided only at a premium, and this may expose innovative firms to financial constraints (Hall, 1992; Carpenter et al., 1998; Harhoff, 1998; Mulkay et al., 2001; Bond et al., 2010; Brown and Petersen, 2009, 2010; Lee et al., 2015).

In this paper, we investigate the relationship between the types of external capital obtained by firms and the firms' innovation characteristics. We focus on the issue of informational transparency and assess the role of innovation signals among the factors that shape the hierarchy of financing decisions. Our results demonstrate that the allocation of external finance is significantly influenced by the borrower's innovation profile, and show how different dimensions of innovation associated with varying degrees of risk affect the pecking order of external capital.

Our results support the hypothesis that asymmetric information drives financing outcomes. We show that innovation characteristics of a firm that proxy for information asymmetries shape the pecking order of its financing choices. Effects are strongest for input factors, such as R\&D, patent, intellectual property (IP) protection, and human capital, and weaker for realised innovations. For innovative firms, therefore, the pecking order is reversed. The ability to distinguish distinct classes of external finance enables tests of a-priori and data- 
derived orderings of financing outcomes, which produce nearly identical results and support the impact of information asymmetries on the pecking order.

We study innovation as a source of agency costs among small and medium-size enterprises in a context where information asymmetries are especially severe. We use data from an original survey of UK and US SMEs which include information on firm financing alongside several indicators of innovation. While other data sources used in the literature provide detailed information on either the former or the latter, joint coverage of financing and innovation activities is rare. On this basis, we extend capital structure theory by identifying innovation as a source of asymmetric information that can explain systematic deviations from the standard pecking order of increasing agency costs. Moreover, while previous research has studied firm characteristics derived from financial accounts, capital market data or market microstructure as proxies for asymmetric information (Bharath et al., 2011, 2009; Leary and Roberts, 2010), we bring to the fore the role of different dimensions of innovation (inputs, intermediate outputs and outcomes) and their importance for the financing of SMEs.

The paper is structured as follow. In section 2 we review the relevant prior art and develop testable hypotheses on the effect of innovation on the pecking order of external finance. In Section 3 we present our data and methods of analysis. Section 4 contains the main results of the paper, which we discussed in the following section (5). Section 6 concludes with a more general reflection on the contribution of the paper and its implications for further research.

\section{The hierarchy of financing decisions and their determinants}

The pecking order hypothesis predicts that borrowers follow a specific order of preferences for different types of finance as a result of information asymmetry between well informed managers and less informed investors. In the first instance, firms will fund new projects with internal resources (i.e., operating cash flow) and will seek external finance only when 
available internal funds have been exhausted (Myers, 2000; Myers and Majluf, 1984). If they cannot access internal funds, firms will prefer debt over equity among alternative sources of external capital (see also Harhoff, 1998; Himmelberg and Petersen, 1994). Debt is a more senior form of capital and thus less sensitive to private information than equity. Since equity is the relatively more expensive option associated with the most severe information asymmetries, firms will issue equity only when they have exhausted their debt capacity (Lemmon and Zender, 2010; Myers, 1984). In an attempt to minimise adverse selection costs, firms will therefore use internal finance first, then debt, and finally equity.

Despite a considerable amount of theoretical and empirical studies on this topic, there is no consensus in the literature on the extent to which pecking order theory is able to explain the financing behaviour of firms, as suggested by Shyam-Sunder and Myers (1999), and the predictive power of this hypothesis has not proved universally superior to alternative explanations (de Jong et al., 2011; Leary and Roberts, 2010; Fama and French, 2005; Frank and Goyal, 2003). There are different interpretations and technical implementations of the theory's building blocks (Lemmon and Zender, 2010; Leary and Roberts, 2010). Moreover, it has proved difficult to generalise the conditions under which the pecking order should apply, with the consequence that different views persist on the merits of pecking order relative to competing theories of capital structure (e.g., dynamic and static trade-off theory). The debate is especially contentious on the relative merits of equity vs. debt as external sources of finance, whereas empirical studies tend to confirm the prediction of pecking order theory about the preference for internal over external finance, as demonstrated by Frank and Goyal's (2008) review of the determinants of leverage. Under fairly weak assumptions about the existence of transaction costs, internal funds will be preferred (Kaplan and Zingales, 1997).

Our goal in this paper, however, is not to compare the relative merits of pecking order theory and competing theories but to test to what extent firms' innovation activities are related 
to the central element of pecking order theory, namely asymmetric information, and can help explain the observed financing behaviour of firms. Bharath et al. (2009) derive a proxy for asymmetric information from market microstructure information (including liquidity and the probability of informed trading) and find that firms with greater information asymmetry are more likely to cover financing deficits by issuing debt. Firms in Lipson and Mortal's (2009) study prefer raising equity when their equity is more liquid. Bharath et al. (2011) study lending relationships and find that spreads charged for relationship loans are lower if the firm is larger by assets, has public rated debt, or is an S\&P 500 index constituent. What these indicators and relationship lending have in common is the availability of public information on the firm. This suggests that firm characteristics which make it difficult to assess the firm's prospects should reduce the likelihood of finding external finance that relies on externally verifiable information about the firm (e.g., to forecast the potential breach of debt covenants). Among these characteristics, the literature discusses at length the role of firm size in selecting the most appropriate theory of capital structure. For smaller firms, the information that is available to investors for the evaluation of investment opportunities can be seriously limited by the absence of a track record and lack of collateral. However, on the basis of pecking order theory it is not entirely clear whether SMEs should behave differently from larger firms, other things being equal, unless credit rationing makes debt unavailable to SMEs and leaves equity as the only means of external financing. Frank and Goyal (2003) and Fama and French (2005) argue that small, high-growth firms are more sensitive to asymmetric information problems. They would therefore rely on equity rather than debt when they need external finance (Devos et al., 2012) as a reflection of financial constraints rather than a contradiction of pecking order (Chang and Song, 2013). While small firms may have high growth rates more often than large firms, however, it is the growth characteristic of a firm, not its size as such, which makes it opaque to investors. It is possible, as Frank and Goyal 
(2008:22) write, that "when there is asymmetric information about risk, adverse selection arguments for debt apply and firms prefer to issue external equity over debt. Thus, adverse selection can lead to a preference for external debt or external equity depending on whether asymmetric information problems concern value or risk."

An additional layer of complexity has been added to modern capital markets by the rise of entrepreneurial finance, which has substantially enriched the range of external sources of capital available to firms, and in particular to SMEs (Chemmanur and Fulghieri, 2014). This increases institutional variety and adds further options to the spectrum of finance types beyond a 'simpler' choice between debt and equity. Specialist investors can contribute greater expertise in evaluating the commercial prospects of the firm's growth potential relative to traditional lenders, and venture capitalists have proved to be especially skilled at handling the high risk of new entrepreneurial activities (Goldfarb et al., 2013; Wong et al., 2009; Gompers and Lerner, 2001, 1999; Harrison and Mason, 2000).

Berger and Udell (1998) elaborate on the idea of a finance continuum where insider finance, angel finance, private and public equity, different forms of lending and trade credit co-exist as alternative or complementary sources of finance, and the likelihood that they come into use varies with firm size, age and availability of information. The central idea is that firms will pursue different types of capital over time and will change capital structures over their life-cycle. When they are young, firms will use internal funds. They will then access different forms of debt and/or equity finance as they grow older and larger, and accumulate collateralisable assets, learn about lending technologies, and comply with stricter information disclosure protocols (Berger and Udell, 2006; Guiso, 1998). ${ }^{3}$ An increase in the institutional variety of external capital markets may not violate the principles of pecking order theory but

\footnotetext{
${ }^{3}$ The empirical evidence is also mixed on the effects of age on the pecking order, as discussed by Robb and Robinson (2014), who find from analyses of the Kauffman Survey that new firms are more likely to obtain debt than equity despite the possible revealed preference for equity given the financial constraints that characterise start-up firms.
} 
extend the hierarchy of financing behaviours. The result is an extended pecking order that includes - by increasing levels of information asymmetry - debt, public equity, private equity and angel finance.

\section{Innovation, asymmetric information and the pecking order.}

Innovation is a strong theoretical candidate to explain the empirical patterns observed in firms' financing behaviour on the basis of large information asymmetries that cause firms and investors to choose the financial options that best address the resulting agency problems. Innovation activities decrease the transparency of firms as investment propositions because of the uncertain nature of technical change and the market risk associated with new products and processes. R\&D requires long-term investments and its output can often be characterised by radical (Knightian) uncertainty. In addition, $R \& D$ involves the accumulation of idiosyncratic intangible capital, such as intellectual property and skills, that are difficult to resell on a secondary market if the project fails to achieve its desired targets. Finally, new products and new processes may emerge as the successful outcomes of R\&D processes, even though their returns are not guaranteed given the unpredictability of potential demand (Hall 2010).

From an investment point of view, the evaluation of R\&D projects calls for different competences (for example, a degree of technical or scientific knowledge) and different propensities to risk in comparison with ordinary investments. Low informational transparency can result in limited supply - or no supply at all - of different forms of external capital. The literature has been quite clear that $R \& D$ can exacerbate firm financial constraints (Brown and Petersen, 2010, 2009; Bond et al., 2010; Mulkay et al., 2001; Harhoff, 1998; Hall, 1992). What are then the implications of innovation for the hierarchy of financing decisions?

Since transaction costs can generate a wedge between the cost of external and internal funds in any firm, there is no theoretical reason to believe that there should be a difference between innovative and non-innovative firms in having a preference for internal cash resources 
as the more advantageous financing option. The available empirical evidence is very clear on the predominant role of internal resources for innovation (Bakker, 2013; Mina et al., 2013; Revest and Sapio, 2011; Czarnitzki and Hottenrott, 2011; Vanacker and Manigart, 2010; Cosh et al., 2009; Hall, 2010; Hall and Lerner, 2009). The question whether debt or equity should be preferred by more innovative firms once internal resources are exhausted is rather more complicated, because innovative firms can be valuable investment opportunities, hence suitable for debt financing, but are also considerably riskier and prone to agency costs, hence more suitable for equity financing (Aghion et al., 2004).

Robb and Seamans (2014) show that information asymmetries are especially severe between entrepreneurs (as owner-managers of younger firms) and lenders, and that the problem will be made worse by lack of tangible assets and concurrent reliance of intangibles. Moreover, and in line with transaction cost theory, they find that firm-specific assets as indicated by $R \& D$ activities induce a greater likelihood of equity financing relative to debt. ${ }^{4}$ Cosh et al. (2009) consider the effect of introducing an innovation, but not the effect of R\&D expenditure, and find a weak negative result for the percentage of external finance obtained by the firm, and overall inconclusive results for the main sources of external capital considered one at a time. Fulghieri et al. (2015) argue that deviations from the pecking order are possible when some of the firm's assets are more exposed to private information than other assets. In this case, young firms with large investment needs and firms with risky and valuable growth options will first access equity and then revert to debt as they mature.

Among external sources of capital, some investors have the potential to increase firm value beyond the provision of financial resources per se, as is strongly emphasized in the literature on angel (Wong et al., 2009; Harrison and Mason, 2000) and venture capital (VC)

\footnotetext{
${ }^{4}$ This is also confirmed by resource-based views of firm capital structure as discussed, for example, in VicenteLorente (2001) and Wang and Thornhill (2010). Rostamkalaei and Freel (2016) also show that the cost of debt finance is higher for growing innovative firms.
} 
finance (Schwienbacher, 2008; Riyanto and Schwienbacher, 2006; Mayer et al., 2005; Neus and Walz, 2005; Bascha and Walz, 2001; Kortum and Lerner, 2000; Gompers and Lerner, 1999; Bergemann and Hege, 1998). In addition to higher technical and scientific knowledge and human capital, venture capitalists employ a variety of instruments (splitting investments in multiple stages, taking seats on the portfolio companies' boards or aligning management incentives with stock options or similar remuneration schemes) that mitigate information problems at the stage of screening and monitoring (Casamatta and Haritchabalet, 2007; Manigart et al., 2006; Kanniainen and Keuschnigg, 2004, 2003; Hsu, 2004; Casamatta, 2003; Gompers and Lerner, 2001, 1999). The superior skills of venture capitalists at the screening stage are especially important for small innovative firms seeking investment, as reflected in the substantial difference theorized between VC finance and institutional (debt) investors (Bettignies and Brander, 2007; Keuschnigg and Nielsen, 2004; Ueda 2004; Berger and Udell, 2002). Venture capital will be especially sensitive to signals of innovation potential.

Summarizing the theoretical predictions about information asymmetries and firm characteristics, we expect that the more innovative firms will be less likely to obtain debt relative to equity and risk capital. We formulate the following hypothesis:

Hypothesis 1: Innovation decreases the probability of debt financing but increases the probability of equity, and venture capital in particular.

We also expect that innovation will generate a systematic deviation from a standard pecking order of preferences in which firms should first access the source of finance associated with lower agency costs and then move on to the relatively more expensive source. Information asymmetries induced by innovation will increase agency costs across the whole hierarchy of financing decisions and the greater these information asymmetries the lower the 
probability that firms will access external capital following an order of increasing agency costs. We therefore hypothesize that:

Hypothesis 2: Innovation is negatively associated with a standard pecking order characterised by increasing agency costs of external finance.

Innovation can be characterised by several dimensions associated with varying degrees of risk and with more or less symmetric distributions of information about outcomes. R\&D expenditures and unreported $R \& D$ activities form the basis of fundamentally uncertain innovation processes. As an input factor rather than an output of innovation, $R \& D$ bears the highest risk for investors (Hall, 2010). Further along the innovation process, patents can be seen as an intermediate outcome of $\mathrm{R} \& \mathrm{D}$, signalling successful research or development, or as an input for the firm's future technology and market developments. Since firms tend to patent only what is deemed worthy of legal protection and because patents are public documents, they are also stronger (more informative) signals of potential value (Conti et al., 2013; Harhoff, 2009; Hsu and Ziedonis, 2008; Lemley, 2000). This protection mechanism of a firm's intellectual property also reduces the market risk of innovation because it provides a statutory barrier to imitation (Trajtenberg and Jaffe, 2002). Finally, successful exploitation of innovation inputs results in superior products or methods of production. The introduction of tangible new products and processes will be an observable outcome of innovation and will further reduce information asymmetries about the firm's prospects.

Frank and Goyal (2008) propose that if asymmetric information is due to risk, then adverse selection arguments for debt will apply, and not only would we observe deviations from the standard pecking order, but we would have stronger effects for innovation activities that bear the greater risk (and are weaker indications of value). We expect that: 
Hypothesis 3: The greater the information asymmetry of innovation activities, the stronger their effects on the pecking order of external finance.

\section{Data and methodology}

\subsection{Data Sources}

The dataset we use in this paper is derived from a unique survey of UK and US businesses jointly carried out by Centre for Business Research (CBR) of the University of Cambridge and the Industrial Performance Center of MIT in the period 2004-2005. The sampling frame for the survey is the Dun \& Bradsheet (D\&B) database, which includes company-specific information drawn from various sources (Companies House, Thomson Financial, and press and trade journals). The original sample covers all manufacturing and business service sectors. It is stratified by sector and employment size $(10-19 ; 20-49 ; 50-99 ; 100-499 ; 500-$ 999; 1,000-2,999; and 3,000+). Larger proportions were taken in the smaller size bands because in both the U.S. and the U.K. the vast majority of businesses (more than 98\%) employ fewer than 100 people. The data were collected through a telephone survey between March and November 2004, followed by a postal survey of large firms spring 2005, which generated a total sample of 1,540 U.S. firms and 2,129 U.K. firms.

One of the original features of the survey is that it covers detailed questions about the firms' innovation activities, as is typical of the European Community Innovation Surveys (CIS), alongside questions about the businesses' financial profile, which in the standard CIS are limited to the degree to which the availability or the cost of finance constitute barriers to innovation. This survey contains less information on firm capital structure compared to the Kauffman surveys (DesRoches et al., 2013), but has more information about firms' innovation inputs, processes and output. The dataset provides separate firm-level observations 
for the type of finance (debt, equity and what form of equity) firms obtain. Contrary to most empirical studies on this topic, this information does not constitute an ex ante criterion for sample selection, as is often the case for research-based on investor-generated databases (for example, banks' records of loans or VC finance databases such as VentureXpert). Moreover, the dataset is not limited to start-up firms from the same cohort.

\subsection{Sample}

Our sample comprises firms in the CBR-MIT survey that obtained finance in the two years prior to being interviewed. This generates a working sample of 851 firms, 454 in the U.S. and 397 in the U.K. Firms answered the survey questions almost completely. There are some gaps in the data across variables, however, which would have prevented us from using a substantial portion of the survey responses. In particular, firms are often reluctant to answer questions about profitability and R\&D spending. In addition, firm size prior to the survey is missing for about a quarter of firms. In order to avoid the loss of observations due to missing values, we first substitute missing values with company accounts data available through the FAME database. The remaining missing values are imputed by random regression imputation (Gelman and Hill, 2006) to replicate the correlation structure among explanatory variables. ${ }^{5}$ The number of imputations is generally low and below 5 percent per variable for all variables except firm size, R\&D expenditures and internationalization (see Table 2 for descriptive statistics and information on imputed data; variables are defined in Table 1).

Ratios calculated from survey variables, such as profit margins or R\&D intensity, are censored at the 1 percent and $99 \%$ quantile before imputation to eliminate outliers with implausible values. Finally, we winsorize variables that are not themselves imputed but which are obtained by dividing two other variables at the 2 percent and 98 percent quantile. If values

\footnotetext{
${ }^{5}$ All relevant details on the imputation method we used, including a description of step-by-step process we followed for each variable, are available from the authors upon request.
} 
are missing in our dependent variables, we drop these observations, which slightly reduces the sample size available for individual regressions.

$<<$ Insert Tables 1 and 2 about here $>>$

\subsection{Dependent variables and estimation strategy}

The dependent variables in this paper are constructed from survey items that ask firms whether they obtained finance from a set of sources. On one dimension, firms may obtain finance in the form of equity, debt or "other" types of finance or any combination of them. As a second dimension to these financing decisions, firms may obtain funds from venture capital firms or informal venture capital, the latter of which includes business angels. These two dimensions generate 29 possible combinations, of which 26 are occupied by the firms in our sample. Figure 1 shows the absolute frequencies across combinations while Table 2 includes relative frequencies for each dimension. Table 4 shows correlation coefficients for the dependent and independent variables. Firms obtained debt more often than equity, with 78 percent of firms obtaining some amount of debt compared with 30 percent of firms obtaining equity. About 8 percent of firms said they received funding from venture capital firms, while 5 percent received informal VC support. About 15 percent of firms received a combination of equity and debt in the two-year period prior to the survey.

$$
<<\text { Insert Figure } 1 \text { about here }>>
$$

We use as dependent variables: firstly, success at obtaining any amount of the different sources of finance; secondly, the observation that any one type of finance is the dominant form of external capital (i.e., it accounts for the largest share of the external financing 
received by the firm); and thirdly, different combinations of sources of finance defined as follows. We organise the combinations identified in Figure 1 into financing classes that are consistent with pecking order theory and can therefore be used to test hierarchical outcomes. These classes are shown in Table 3. We test pecking orders consisting of 4, 6, and 8 mutually exclusive classes. The 4-class model includes a) firms that obtained any kind of venture capital, b) those that obtained equity but no $\mathrm{VC}, \mathrm{c}$ ) those that obtained debt but no equity or $\mathrm{VC}$ and d) firms that obtained funds from other sources but no VC, equity, or debt. The pecking order with 6 classes allows for co-occurrence of sources of finance and a pecking order with 8 classes of finance includes combinations that distinguish between venture formal and informal sources of entrepreneurial capital. These orders reflect the variations in agency costs derived by pecking order theory.

$<<$ Insert Tables 3 and 4 about here $>>$

\subsection{Independent variables}

The primary focus of this study is on the effects of innovation on the financing decisions firms make. R\&D intensity is the preferred choice to capture innovation activity according to standard practice in the literature (Hausman et al., 1984; Pakes and Griliches, 1980). Since prior innovation research has used a range of measures, including the logarithm of R\&D expenditures, $R \& D$ expenditures scaled by various size variables, or the number of $R \& D$ employees, we choose a suitable combination of these indicators: We proxy for size by taking the logarithm of employment and control for R\&D intensity by including the ratio of R\&D expenditure and the firm's sales. This allows us to avoid the use of multiple size-dependent measures. Tables 2 and 4 show summary statistics and correlation for the variables used in our analyses. 
Contrary to the vast majority of prior contributions, we are not limited to the use of one indicator of innovation - R\&D - in our analysis of the market for external finance. It can be argued that indicators of innovation might have different effects from R\&D on the supply of capital given the easier access to information by investors in the case of tangible innovation outputs relative to innovation inputs that may or may not turn into profitable products. As called for by Aghion et al. (2004) and Hall (2009), we address this problem with a richer set of indicators of innovation that include input (R\&D intensity), intermediate output (patents) and innovation output (product and process innovations). These indicators are associated with different levels of risk and different degrees of information asymmetries between potential borrowers and lenders and can provide powerful insights into financing behaviours. We further include the (log) number of patents. Patents may, on the one hand, be an indicator for opaque intangible capital and aggravate financial constraints. On the other hand, the certification effect of patent authorities granting a patent involves lower information asymmetries than the observation of R\&D activities and, as a statutory barrier to imitation, increases the likelihood of future returns. We then include indicators for whether the firm has introduced a product or service that is new to the industry, or a novel manufacturing or service process that is new to the industry.

We further include in our analysis information on intellectual property protection mechanisms. Forms of intellectual property protection other than patents can include formal (e.g., copyright, non-disclosure agreements) and informal mechanisms (e.g. secrecy, complexity of design, time to market). These mechanisms can play a role as buffers against risk but are also an indication of intangible assets which reduce the transparency of the firm as an investment opportunity. The overall attitude of the firm towards protecting its IP may be highly relevant. The value of IP remains unproven prior to the test of the market and crucially depends on subjective judgments made by stakeholders. A trade-off might arise because of an 
agency problem between borrower and lender that is easily traceable to the economic problem of the public nature of information. On the one hand, investors will want to invest in a product or service that cannot be freely imitated by competitors and will be sensitive to the strategies put in place by firms to protect their know-how. On the other hand, lenders, who will share the objective of protecting IP, might be reluctant to disclose private information to external agents, but these might include other investors. Since the financing process entails the disclosure of private information, unwillingness to share information is likely to affect financing decisions. As a consequence, over-protectiveness can have significant detrimental effects not only on the firm's innovative performance (Laursen and Salter, 2005), but also a direct negative effect on the probability that firms obtain external finance. To control for these effects, we include in our models an index of the breadth of IP protection that is constructed as the number of innovation protection methods used by the firm (registration of design, trademarks, patents, confidentiality agreements, copyright, secrecy, complexity of design, and lead-time advantage on competitors).

Finally, we include as part of a firm's innovation profile information about its human capital, because firms with larger proportions of human capital tend to have fewer tangible assets, which in turn aggravates potential financing problems. We measure human capital as the fraction of employees holding a university degree and expect it to be negatively associated with the likelihood of obtaining debt finance as a reflection of a greater degree of intangible capital in knowledge-intensive businesses. In addition, we measure CEO education with two dummy variables indicating whether the $\mathrm{CEO}$ has a $\mathrm{PhD}$ or an MBA.

Our control variables include essential firm characteristics such as size, age and industry. We expect larger and older firms to be more likely to access debt markets than younger and smaller and more financially constrained firms. Because we are interested in differences across firms due to their innovation profile, we classify industries according to the 
OECD (2005) classification of research-intensive industries and use dummy variables for broad industry affiliation to control for sectoral effects. Businesses in high-tech industries and those with substantial intangible capital should be more opaque and may obtain equity relatively more often than debt compared with other firms (Fan et al., 2012).

We further include measures of market scope (measured by the degree of internationalization), intensity of competition, firms' growth ambition, profitability and whether the firm is an independent entity. Higher profitability typically leads to a lower dependency on equity finance due to the firm's ability to contract on existing and positive operating cash flows for which profits can be seen as a proxy. The growth orientation of firms, which is likely to require funding of uncertain expansion investments, should lead to lower probability of obtaining debt or instruments that rely on collateral or easily measured covenants. A firm's degree of internationalization, or, more precisely, the part of internationalization that is unrelated to firm size may impair an assessment of the firm's prospects by outside investors who may thus require compensation for the added risk. A larger number of competitors, on the other hand, can signal a well-established market with many parties producing information about future returns in this market. This transparency would then lead to easier access to finance. We expect subsidiary firms to have advantages compared with independent firms when raising finance due to the parent's informational advantage and the ability to sometimes rely on the parent's assets as collateral.

\subsection{Estimation strategy}

The data we use in this paper are cross-sectional and might pose endogeneity problems. In order to reduce this risk, wherever possible we use lagged values referring to the beginning of the period of observation for the regressors, which are derived from specific questions on the firm's characteristics or behaviours three years prior to the survey (i.e., in 2000/2001). These lagged observations are not available for our indicators of innovation, but it is very unlikely 
that causal mechanisms could go from the probability of obtaining finance to innovation over the same period given that any investment in innovation takes time to generate any outcome. ${ }^{6}$ In addition, even though the survey asks respondents about their innovation activities during the previous 3 years, the financing questions targeted the shorter period of the previous 2 years, thus further reducing endogeneity risks.

In a first set of models, we estimate the likelihood that a firm obtains any one of the distinct types of finance regardless of whether any other funding was obtained by the firm. In a second set of models, we classify firms according to the dominant source of finance and estimate multinomial logit models for the relative likelihood of obtaining any particular type of finance. Finally, since pecking order theory is concerned with the hierarchy of financing decisions we use ordered probit models to test the explanatory power of innovation for the set of hypothesized pecking orders with 4, 6 and 8 classes of external financing. This is a direct and systematic test of pecking order theory which, to the best of our knowledge, is absent from the literature.

\section{Results}

Financing decisions are tightly linked to the innovation profile of a firm. Results from our first set of probit models for the likelihood that firms obtain any amount of different types of finance show that according to expectations $R \& D$ is positively associated with equity and negatively associated with debt (see Table 5). Patents also have significant positive and negative effects, respectively, on equity and debt. Human capital employed by the firm has

\footnotetext{
${ }^{6}$ It is important to make a theoretical judgment about the structure of the data because even lagged values in time series may not be sufficient to resolve the question of causality if observations of innovation or related firm characteristics exhibit low variation over time. Only long panels could purge the data of unobservable firm heterogeneity, but these are very rarely available. Here we follow Cosh et al. (2009), who argue that external finance does not have a contemporaneous effect on profitability, turnover or profit margin in the same year, and obtaining finance will not lead to an innovation in the same year. They therefore use the current capital expenditures to account for planned growth (i.e., not historical capital expenditures which reflect historical growth) and for the fact that firms disclose to potential lenders their most recent quarter profits and capital expenditures, as well as expected profits and capital expenditures.
} 
similar and highly significant effects on the choice of equity or debt, which hints at an important role of input factors to innovation in these financing decisions. Firm with higher degrees of innovation inputs with typically uncertain outcomes record more equity and fewer debt financing events, in line with hypothesis 1.

Venture capital responds positively and significantly not only to input measures of innovation, such as R\&D and human capital, but also to output measures. Process innovation and IP protection are associated with VC financing, but disaggregation of formal and informal venture capital shows that formal VC is attracted by process innovators, whereas informal VC (angel investors) is more likely to invest in firms with new products. While both types of investors invest in firms that protect their intellectual capital, formal venture capital is more likely to flow into firms with an established patenting record. These results suggest that these investors specialise in different stages of the firm's life cycle that are characterized by varying degrees of uncertainty about innovation outcomes.

The direction of these effects can be interpreted coherently if the innovation measures in our models capture uncertainty about the firm's investment projects and associated agency risks. Debt finance typically relies on collateral or debt covenants, both of which are usually not available in early-stage firms characterized by large R\&D expenditure, production of intangible capital and lack of internal cash flow. Venture capitalists specialise in such situations through screening and monitoring practices, as well as contract design, which enables them to reduce some of the information asymmetries present in these firms (Gompers, 1995). It is this likely that financing choices are driven to a large extent by information asymmetries generated by firm's innovation activities.

$<<$ Insert Table 5 about here $>>$ 
When we consider the probability that firms obtain the largest share - and not only any positive amount - of their external capital from different types of finance, results are very similar. Multinomial logit models in Table 6 show negative effects of R\&D on debt (relative to equity), and positive effects of R\&D on venture capital (relative to other forms of equity). Results for patents and human capital are consistent with the previous results obtained from probit models. We can therefore conclude that our results support hypothesis 1 that innovation decreases the probability of debt financing but increases the probability of equity and VC, consistent with the view that asymmetric information drives the pecking order.

Among the additional indicators of intangibles, we find a positive effect of the CEO having a $\mathrm{PhD}$ on the likelihood that the firm obtains informal venture capital, which can be interpreted as a sign of the high-tech nature of the firms backed by informal venture capital, and a positive effect of the CEO having an MBA on the likelihood of obtaining formal venture capital. This result is not as significant as the effect of R\&D and human capital, but it is nevertheless quite interesting, as it seems to point to the value of acquiring skills such as business planning or the importance of social capital generated through the MBA course, which enables CEOs to reach out to the investors' community.

$<<$ Insert Table 6 about here $>>$

Results for control variables in probit models shown in Table 5 reveal that older firms are more likely to obtain debt and less likely to obtain equity and $\mathrm{VC}$, in line with the view that more information is available about older firms, which also tend to have a greater proportion of tangible assets in place. Firm size is not positively associated with debt when controlling for age, and it seems that the larger firms in our sample have an advantage in accessing formal venture capital. It is possible that the larger firms in our sample of SMEs, 
which are not large by standard definition, maintain an informational advantage due to size in relation to VC investments. The size of investments by venture capital firms is further bounded from below, since VC funds often face high fixed costs of investment that is only possible to be outweighed by high expected portfolio returns for large investments. These results are consistent with the results obtained from multinomial logit estimations (Table 6) where older firms are more likely to obtain debt relative to equity and less likely to obtain venture capital, while a larger size helps to obtain venture capital. Among the stronger predictors of debt relative to other sources of finance included in the model, profit margin exerts a strong positive effect, which is perfectly consistent with the theoretical predictions about cash flow. ${ }^{7}$

We test the role of innovation in the hierarchy of financing decisions - and not simply in decisions about individual sources or between pairs of sources - by applying ordered probit modelling to our data. Table 7 presents the results we obtain from estimating the effects of innovation variables on the hypothesized orderings of 4 (Model 1), 6 (Model 2) and 8 (Model 8) classes of external financing. The models are consistent in identifying significant negative effects of R\&D and patents on the standard pecking order characterised by increasing agency costs (i.e., an order from debt, to equity, to formal VC, to informal VC). Both product and process innovations generate insignificant results instead. The indicators of intangibles that induce strong information asymmetries (human capital staff and breadth of IP protection mechanisms) have consistently significant and negative effects on the pecking order. As far as IP protection mechanisms are concerned, it appears that the negative effect of uncertainty about innovation outcomes dominates the positive effect of their role as barriers to imitation and indicators of future value. The loadings of our innovation measures on the latent variable

\footnotetext{
${ }^{7}$ The effect of profit margin on equity was negative in the previous set of probit models - a possible indication of financial constraints, but this effect disappears when equity is compared to debt, which is relatively more responsive to cash flow, in line with theory.
} 
underlying the ordered probit models based on a-priori theoretical arguments about agency costs in different classes of finance suggest that we are indeed capturing agency costs. Since innovation as a source of asymmetric information is negatively associated with the standard pecking order, these results corroborate hypothesis 2 .

$<<$ Insert Table 7 about here $>>$

The effect of age follows our expectations. Firms approach the different sources of finance in the sequence described by life cycle theory (i.e., starting with venture capital or other forms of equity associated with greater agency costs and then moving on to debt as they get older). Size, however, does not behave as expected from the argument that smaller firms are more opaque investment propositions and will be at a disadvantage in accessing the more senior type of finance. The effect of size on the pecking order is negative. This means that if we can account directly for more sources of asymmetric information, such as innovation activities, size per se may also be related to asymmetric information (through the complexity of the business) which prevents SMEs from following their preference for debt according to a standard pecking order. The effects of profitability are in line with the pecking order: coefficients are positive and highly significant in all models and support the expected relationship between cash flow and the pecking order. It is also worth pointing out that the degree of internationalization of the firm, a plausible sign of a dynamic business, is positively associated with the standard hierarchy of financing decisions, as it signals to external finance providers a good opportunity for investment that dominates the potential effect of greater complexity and risk in international businesses.

Our final hypothesis concerns the informational content of different innovation activities. We argue that there are different dimensions to innovation and that innovation 
inputs (R\&D), intermediate output (patents) and the market introduction of new products and processes corresponded to different degrees of uncertainty about the likelihood of innovation outcomes and thus increases in firm value. $R \& D$, as the most uncertain activity, is expected to induce the greatest information asymmetries and exert the strongest negative effect on the standard pecking order, followed by patents, and then by indicators of successfully achieved innovations.

These expectations of the differential impact of innovation measures on the pecking order are supported by our regression results in Table 7. R\&D systematically exerts the strongest effect on the hierarchy of financing decisions if measured by the impact of a one standard deviation change in each variable on the pecking order. $R \& D$ also has the greater statistical significance, but the coefficients' covariance is too large to detect a statistical difference between R\&D and patents. Patents also generate increasing agency costs, but their effect is slightly weaker compared to the effect of R\&D. The effects of revealed innovations, however, are not significant after accounting for R\&D and patenting: investors are able to observe the outcome of innovation activities, and this will eliminate or dramatically reduce information asymmetries. This result is plausible because the R\&D project - with some form of IP protection - has delivered. If information asymmetries are reduced, so will be the relevant agency costs, and indicators of realised innovation will no longer generate a deviation from the standard pecking order. Hypothesis 3 is therefore confirmed.

\section{Additional tests}

\subsection{An emerging pecking order of innovation finance}

In addition to our main estimations we run two sets of further analyses to validate our findings. In the first set of analyses we explore the extent to which the ordering of external financing reflects the hierarchy of financing decisions when not constrained by theoretical considerations. Rather than estimate the hypothesized pecking orders, we identify the orderings that best fit the 
unordered classes of external financing. More specifically, we test all permutations of financing classes and select the ordered probit model with the greatest likelihood.

The results we obtain from optimised models are identical to the hierarchy of 4 and 6 classes presented respectively in Model 1 and Model 2 of Table 7. There was only a minor difference in the relative order of formal and informal VC in the model with 8 classes. The likelihood-optimised Model 4 is included in Table 7 beside Model 3, which tests an a-priori theory-driven pecking order, and shows an apparent preference for formal over informal venture capital in a reversed pecking order, although this may simply be due to some in the measure for informal venture capital (e.g., inclusion of instances of finance that are not strictly risk capital associated with control rights). Overall, the similarity between empirically optimised and theory-driven models is a clear indication of strong empirical support for the hypotheses we formulated on the basis of asymmetric information and the agency costs of external finance.

What makes these empirically driven results remarkable is that the latent variable underlying the order of financing classes in our ordered probit models resonates with the direction of the variables measuring the innovation profile of the firm. The likelihood maximization approach to model selection uncovers a latent ordering variable in line with a theory-driven pecking order based on innovation characteristics. $\mathrm{R} \& \mathrm{D}$, patents, IP protection, and the human capital of a firm all strongly affect the latent variable that in turn shifts a firm along the 4, 6, or 8 ordered financing classes in our models. For larger values of these variables, firms will have financing events that are more likely to be associated with venture capital and equity. Pure debt financing is found in firms with lower values of $R \& D$, patents, IP protection, and human capital. 


\subsection{Sample split by country}

The second additional test concerns the two institutional settings from which the sampled companies are drawn, the UK and the US. It is important to control for the country of origin of the firm because this may reflect a priori differences between external capital markets, which may bias results if they are left unaccounted for. The models in Table 5 and Table 6 reveal, perhaps surprisingly, that US firms are less likely than UK firms to obtain venture capital. ${ }^{8}$ Clarysse et al. (2009) and Bottazzi and Da Rin (2002) note that in the mid-2000s in the UK there was no shortage of external finance for firms seeking it. In particular, VC finance was available but it was distributed rather 'thinly', while the US market was characterised by larger volumes of VC with more concentrated distributions across firms. The country dummy is also significant in the pecking order models (Table 7). This seems to indicate that the hierarchy of financing decisions is more marked in the US than in the UK and could be explained by a greater maturity or greater discipline in US external capital markets which makes the relationship between external finance and firm characteristics more predictable. We split the sample by country and run additional tests with four classes of external financing.

Results of this analysis by country are shown in Table 8 . All coefficients discussed above pull in the same direction for the two subsets of observations. The models lose statistical power since we have fewer observations per class of external financing, but confirm that there are stronger results for indicators of innovation in the US system, which seems to be relatively more sensitive to firm characteristics from a financing perspective.

\footnotetext{
${ }^{8}$ Table 5 shows that US firms are also more likely to obtain debt finance, but this result is not significant in the multinomial logits presented in Table 6 .
} 


\section{Conclusion}

Within the extensive literature on the determinants of firms' capital structure, the pecking order hypothesis has received considerable attention. However, doubts remain on both theoretical and empirical grounds about its predictive power since several observed deviations from it do not fit with the standard pecking order of increasing agency costs. Among SMEs populations there are overall clear indications that internal finance is preferred to external finance where available, but there is no consensus on the relative propensity of firms to favour debt over equity and on the contexts in which this expectation may or may not be met. This is an important problem because of the SMEs' share of employment in the macroeconomy and because of their contribution to economic growth (Acs and Audretsch, 1990). Frank and Goyal (2003) and Fama and French (2005) argue that small, high-growth firms do not have a revealed preference for debt over equity because of asymmetric information problems. What type of external capital do SMEs rely on and what drives the hierarchy of their financing decisions?

In this paper, we specifically ask what firm characteristics or what activities induce information asymmetries that produce deviations from the standard pecking order. We argue and show through empirical analysis that innovation can explain such deviations. Innovation shapes the hierarchy of financing behaviours and does so in a way that reflects the informational content of different aspects of the innovation process. We are able to identify the role of innovation inputs, intermediate outputs and innovation outcomes as sources of information asymmetry in an investment framework and also to show that the more uncertain the innovation signal, the stronger its negative effect on the pecking order. Innovation inputs are strongly associated with equity and venture capital as sources of finance, while innovation outputs drive the choice between formal and informal VC. Innovation inputs that are typically associated with agency costs are most strongly related to the theoretically predicted pecking order. This pecking order also emerges from the data when searching for the best-fitting 
ordering of financing classes, confirming that there is indeed a latent variable driving financing outcomes. Our findings based on firm-level proxies for information asymmetries are in line with work by Bharath et al. (2009), who use market microstructure information, and suggest that pecking order theory finds support when its main assumption about asymmetric information holds in the data.

The paper has of course a number of limitations. We are constrained by the crosssectional nature of the data, even though endogeneity risks are reduced by the use of lagged variables and by the favourable time structure of the survey questions about key indicators, in line with recent economic literature on this topic. Of course, more and ideally longitudinal data would allow further experimentation. An interesting set of problems that could be addressed in future research concerns the relationship between the organization of innovation processes within and across firms and the firms' capital structure, which calls into question the strategic interaction between collaborations, IP appropriation mechanisms (control rights over intangibles) and firm financing strategies. This can provide a test bed for the predictive power of the pecking order hypothesis relative to control rights theory. Another interesting path for further research would be a more detailed exploration of the threshold values that punctuate financing hierarchies and their evolution over time in relation to the evolution of R\&D project portfolios. This will of course require more information about the amounts of finance obtained by firms as well as project-level information of firm innovation activities in a longitudinal setting. These data are rare, but would be a powerful platform to further explore the connection between firm capital structure, innovation strategies and firm performance. 


\section{References}

Acs, Z. J., \& Audretsch, D. B. (1990). Innovation and Small Firms, Cambridge, MA: MIT Press.

Aghion, P., Bond, S., Klemm, A., \& Marinescu, I. (2004). Technology and Financial Structure: Are Innovative Firms Different? Journal of the European Economic Association 2(2-3), 277-288.

Bakker, G. (2013). Money for nothing: How firms have financed R\&D-projects since the Industrial Revolution. Research Policy 42(10), 1793-1814.

Bascha, A., \& Walz, U. (2001). Convertible securities and optimal exit decisions in venture capital finance. Journal of Corporate Finance 7(3), 285-306.

Bergemann, D., \& Hege, U. (1998). Venture capital financing, moral hazard, and learning. Journal of Banking \& Finance 22(6-8), 703-735.

Berger, A. N., \& Udell, G. F. (1998). The economics of small business finance: The roles of private equity and debt markets in the financial growth cycle. Journal of Banking \& Finance 22(6), 613-673.

Berger, A. N., \& Udell, G. F. (2002). Small Business Credit Availability and Relationship Lending: The Importance of Bank Organisational Structure. The Economic Journal 112(477), F32-F53.

Berger, A. N., \& Udell, G. F. (2006). A more complete conceptual framework for SME finance. Journal of Banking \& Finance 30(11), 2945-2966.

Berger, A. N., Klapper, L. F., \& Udell, G. F. (2001). The ability of banks to lend to informationally opaque small businesses. Journal of Banking \& Finance 25(12), $2127-$ 2167.

Bharath, S. T., Dahiva, S., Saunders, A., \& Srinivasan, A. (2011). Lending Relationships and Loan Contract Terms. Review of Financial Studies 24(4), 1141-1203.

Bharath, S. T., Pasquariello, P., \& Wu, G. (2009). Does Asymmetric Information Drive Capital Structure Decisions? Review of Financial Studies 22 (8), 3211-3243.

Bond, S., Harhoff, D., \& Reenen, J. V. (2010). Investment, R\&D and Financial Constraints in Britain and Germany. Annales D'Économie et de Statistique 79-80(July-December 2005), 433-460.

Bottazzi, L., \& Da Rin, M. (2002). Venture Capital in Europe and the Financing of Innovative Companies. Economic Policy 17(34), 229-269.

Brown, J. R., \& Petersen, B. C. (2009). Why has the investment-cash flow sensitivity declined so sharply? Rising R\&D and equity market developments. Journal of Banking \& Finance 33(5), 971-984.

Brown, J. R., \& Petersen, B. C. (2010). Cash holdings and R\&D smoothing. Journal of Corporate Finance 17(3), 694-709.

Carpenter, R. E., Fazzari, S. M., \& Petersen, B. C. (1998). Financing Constraints and Inventory Investment: A Comparative Study with High-Frequency Panel Data. The Review of Economics and Statistics 80(4), 513-519.

Casamatta, C. (2003). Financing and Advising: Optimal Financial Contracts with Venture Capitalists. Journal of Finance 58(5), 2059-2085. 
Casamatta, C., \& Haritchabalet, C. (2007). Experience, screening and syndication in venture capital investments. Journal of Financial Intermediation 16(3), 368-398.

Chang, H., \& Song, F. M. (2013). Testing the Pecking Order Theory with Financial Constraints. Working Paper, Available at http://www.efmaefm.org/0EFMAMEETINGS/EFMA\%20ANNUAL\%20MEETINGS/201 3-Reading/papers/EFMA2013_0192_fullpaper.pdf.

Chemmanur, T. J., \& Fulghieri, P. (2014). Entrepreneurial Finance and Innovation: An Introduction and Agenda for Future Research, Review of Financial Studies 27(1), 1-19.

Clarysse, B., Knockaert, M., \& Wright, M. (2009). Benchmarking UK Venture Capital to the US and Israel: What lessons can be learned? Report for the British Venture Capital Association, Available at: https://workspace.imperial.ac.uk/entrepreneurship/Public/BVCABenchmark\%5B1\%5D.pd f.

Conti, A., Thursby, J., \& Thursby, M. (2013). Patents as signals for start-up financing. Journal of Industrial Economics 61(3), 592-622.

Cosh, A., Cumming, D., \& Hughes, A. (2009). Outside Entrepreneurial Capital. The Economic Journal 119(540), 1494-1533.

Czarnitzki, D., \& Hottenrott, H. (2011). R\&D investment and financing constraints of small and medium-sized firms, Small Business Economics 36(1), 65-83.

de Bettignies, J.-E., \& Brander, J. (2007). Financing entrepreneurship: Bank finance versus venture capital. Journal of Business Venturing 22(6), 808-832.

de Jong, A., Verbeek, M., \& Verwijmeren, P. (2011). Firms' debt-equity decisions when the static tradeoff theory and the pecking order theory disagree. Journal of Banking \& Finance 35(5), 1303-1314.

DesRoches, D., Potter, F., Santos, B., \& Sengmavong, A. (2013). Kauffman Firm Survey (KFS) Seventh Follow Up Methodology Report, Final Report, June 27, Available at: http://papers.ssrn.com/sol3/papers.cfm?abstract_id=2286725.

Devos, E., Dhillon, U., Jagannathan, M., \& Krishnamurthy, S. (2012). Why are firms unlevered? Journal of Corporate Finance 18(3), 664-682.

Dosi, G. (1988). Sources, Procedures, and Microeconomic Effects of Innovation, Journal of Economic Literature 26(3), 1120-71.

Fama, E., \& French, K. (2005). Financing decisions: Who issues stock? Journal of Financial Economics 76(3), 549-582.

Fan, J. P. H., Titman, S., \& Twite, G. (2012). An International Comparison of Capital Structure and Debt Maturity Choices. Journal of Financial and Quantitative Analysis 47(1), 23-56.

Frank, M. Z., \& Goyal, V. K. (2003). Testing the pecking order theory of capital structure. Journal of Financial Economics 67(2), 217-248.

Frank, M. Z., \& Goyal, V. K. (2008). Trade-off and Pecking Order Theories of Debt, In: Eckbo, B. (Ed.). Handbook of Corporate Finance: Empirical Corporate Finance, vol. 2, Amsterdam: North Holland, 135-202. 
Fulghieri, P., Garcia, D., \& Hackbarth, D. (2015). Asymmetric Information, Security Design, and the Pecking (Dis)Order, CEPR Discussion Paper No. DP10660, Available at: https://ssrn.com/abstract=2621544.

Gelman, A., \& Hill, J. (2006), Data Analysis Using Regression and Multilevel/Hierarchical Models, Cambridge: Cambridge University Press.

Goldfarb, B. D., Hoberg, G., Kirsch, D., \& Triantis, A. J. (2013). Are Angels Different? An Analysis of Early Venture Financing. Robert H. Smith School Research Paper No. RHS 06-072, Available at: http://ssrn.com/abstract=1024186.

Gompers, P. A., (1995). Optimal Investment, Monitoring, and the Staging of Venture Capital. Journal of Finance 50(5), 1461-1489.

Gompers, P. A., \& Lerner, J. (1999). An analysis of compensation in the U.S. venture capital partnership. Journal of Financial Economics 51(1), 3-44.

Gompers, P. A., \& Lerner, J. (2001). The Venture Capital Revolution. Journal of Economic Perspectives 15(2), 145-168.

Guiso, L. (1998). High-tech firms and credit rationing. Journal of Economic Behavior and Organization 35(1), 39-59.

Hall, B. H. (1992). Research and Development at the Firm Level: Does the Source of Financing Matter? NBER Working Paper No. 4096, Available at: http://www.nber.org/papers/w4096.

Hall, B. H. (2010). The Financing of Innovative Firms. Review of Economics and Institutions $1(1), 1-30$.

Hall, B. H., \& Lerner, J. (2009). The financing of R\&D and Innovation, NBER Working Paper 15325, Available at: http://www.nber.org/papers/w15325.

Harhoff, D. (1998). Are There Financing Constraints for R\&D and Investment in German Manufacturing Firms? Annales d'Économie et de Statistique 49/50, 421-456.

Harhoff, D. (2009). The role of patents and licenses in securing external finance for innovation, EIB Papers 11/2009, European Investment Bank, Economic and Financial Studies, 74-98.

Harrison, R. T., \& Mason, C. M. (2000). Venture capital market complementarities: the links between business angels and venture capital funds in the United Kingdom. Venture Capital 2(3), 223-242.

Hausman, J., Hall, B. H., \& Griliches, Z. (1984). Econometric Models for Count Data with an Application to the Patents-R \& D Relationship. Econometrica 52 (4), 909-938.

Himmelberg, C. P., \& Petersen, B. C. (1994). R \& D and Internal Finance: A Panel Study of Small Firms in High-Tech Industries. Review of Economics and Statistics 76(1), 38-51.

Hsu, D. H. (2004). What Do Entrepreneurs Pay for Venture Capital Affiliation? The Journal of Finance 59(4), 1805-1844.

Hsu, D. H., \& Ziedonis R.H. (2008). Patents as Quality Signals for Entrepreneurial Ventures, Academy of Management Best Paper Proceedings.

Jensen, M. C., \& Meckling, W. H. (1976). Theory of the firm: Managerial behavior, agency costs and ownership structure. Journal of Financial Economics 3(4), 305-360. 
Kanniainen, V., \& Keuschnigg, C. (2003). The optimal portfolio of start-up firms in venture capital finance. Journal of Corporate Finance 9(5), 521-534.

Kanniainen, V., \& Keuschnigg, C. (2004). Start-up investment with scarce venture capital support. Journal of Banking \& Finance 28(8), 1935-1959.

Kaplan, S. N., \& Zingales, L. (1997). Do Investment-Cash Flow Sensitivities Provide Useful Measures of Financing Constraints? Quarterly Journal of Economics 112(1), 169-215.

Keuschnigg, C., \& Nielsen, S. B. (2004). Start-ups, venture capitalists, and the capital gains tax. Journal of Public Economics 88(5), 1011-1042.

Kortum, S., \& Lerner, J. (2000). Assessing the Contribution of Venture Capital to Innovation. The RAND Journal of Economics 31(4), 674-692.

Laursen, K., \& Salter, A. (2005). My precious: The role of appropriability strategies in shaping innovative performance. DRUID Working Paper n. 05-02. Available at: http://www.druid.dk/uploads/tx_picturedb/wp05-02.pdf.

Leary, M. T., \& Roberts, M.R. (2010). The pecking order, debt capacity and information. Journal of Financial Economics 95(3), 332-355.

Lee, N., Sameen, H. and Cowling, M. (2015). Access to finance for innovative SMEs since the financial crisis. Research Policy 44(2), 370-380.

Lemmon, M. L., \& Zender, J. F. (2010). Debt Capacity and Tests of Capital Structure Theories. Journal of Finance and Quantitative Analysis 45(5), 1161-1187.

Lemley, M. A. (2000). Reconceiving Patents in the Age of Venture Capital, Journal of Small and Emerging Business Law 4, 137-148.

Lipson, M., \& Mortal, S. (2009). Liquidity and capital structure. Journal of Financial Markets $12(4), 611-644$.

Manigart, S., Lockett, A., Meuleman, M., Wright, M., Landström, H., Bruining, H., et al. (2006). Venture Capitalists' Decision to Syndicate. Entrepreneurship Theory and Practice 30(2), 131-153.

Mayer, C., Schoors, K., \& Yafeh, Y. (2005). Sources of funds and investment activities of venture capital funds: evidence from Germany, Israel, Japan and the United Kingdom. Journal of Corporate Finance 11(3), 586-608.

Mina, A., Lahr, H., \& Hughes, A. (2013). The demand and supply of external finance for innovative firms. Industrial and Corporate Change 22(4), 1-33.

Mulkay, B., Hall, B. H., \& Mairesse, J. (2001). Firm level investment in France and the United States: A comparison. In Investing Today for the World of Tomorrow. Deutsche Bundesbank.

Myers, S. C. (2000). Outside Equity. Journal of Finance 55(3), 1005-1037.

Myers, S. C., \& Majluf, N. S. (1984). Corporate financing and investment decisions when firms have information that investors do not have. Journal of Financial Economics 13(2), $187-221$.

Myers, S. C., Dill, D. A. and Bautista, A. J. (1976). Valuation of Financial Lease Contracts. Journal of Finance 31(3), 799-819.

Neus, W., \& Walz, U. (2005). Exit timing of venture capitalists in the course of an initial public offering. Journal of Financial Intermediation 14(2), 253-277. 
OECD (2005). Science, Technology and Industry Scoreboard 2005, Paris.

Pakes, A., \& Griliches, Z. (1980). Patents and R\&D at the firm level: A first report. Economics Letters 5(4), 377-381.

Porter, R. H. (1995). The Role of Information in U.S. Offshore Oil and Gas Lease Auction. Econometrica 63(1), 1-27.

Revest, V., \& Sapio, A. (2011). Financing technology-based small firms in Europe: what do we know? Small Business Economics 39(1), 179-205.

Riyanto, Y. E., \& Schwienbacher, A. (2006). The strategic use of corporate venture financing for securing demand. Journal of Banking \& Finance 30(10), 2809-2833.

Robb, A. M., \& Robinson, D. T. (2014). The Capital Structure Decisions of New Firms. Review of Financial Studies 27(1), 153-179.

Robb, A. M., \& Seamans, R. (2014). The Role of R\&D in Entrepreneurial Finance and Performance. In: Villalonga, B. (Ed.). Finance and Strategy (Advances in Strategic Management), vol. 31, Emerald Group Publishing Limited, 341-373.

Rostamkalaei, A. and Freel, M. (2016). The cost of growth: small firms and the pricing of bank loans. Small Business Economics 46(2), 255-272.

Schwienbacher, A. (2008). Innovation and Venture Capital Exits. Economic Journal 118(533), 1888-1916.

Shyam-Sunder, L., \& Myers, S. C. (1999). Testing static tradeoff against pecking order models of capital structure. Journal of Financial Economics 51(2), 219-244.

Stiglitz, J. E., \& Weiss, A. (1981). Credit Rationing in Markets with Imperfect Information. American Economic Review 71(3), 393-410.

Tamari, M. (1970). The Nature of Trade Credit. Oxford Economic Papers 22(3), 406-419.

Trajtenberg, M., \& Jaffe, A. B. (2002). Patents, Citations and Innovations: A Window on the Knowledge Economy. Cambridge, Mass.: MIT Press.

Ueda, M. (2004). Banks versus Venture Capital: Project Evaluation, Screening, and Expropriation. Journal of Finance 59(2), 601-621.

Vanacker, T. R., \& Manigart, S. (2010). Pecking order and debt capacity considerations for high-growth companies seeking financing. Small Business Economics 35(1), 53-69.

Vicente-Lorente, J. D. (2001). Specificity and opacity as resource-based determinants of capital structure: evidence for Spanish manufacturing firms. Strategic Management Journal 22(2), 157-177.

Wang, T., \& Thornhill, S. (2010). R\&D investment and financing choices: A comprehensive perspective. Research Policy 39(9), 1148-1159.

Wong, A., Bhatia, M., \& Freeman, Z. (2009). Angel finance: the other venture capital. Strategic Change 18(7/8), 221-230. 


\section{Figure 1. Types of finance}

This figure shows the composition of our sample with respect to the type of finance obtained by the firm. Because firms can obtain several types of finance at the same time, the graph shows the number of firms that have obtained finance from any combination of sources. For example, 66 firms obtained equity and no other form of finance, and 10 firms have obtained equity finance from an informal venture capital source.

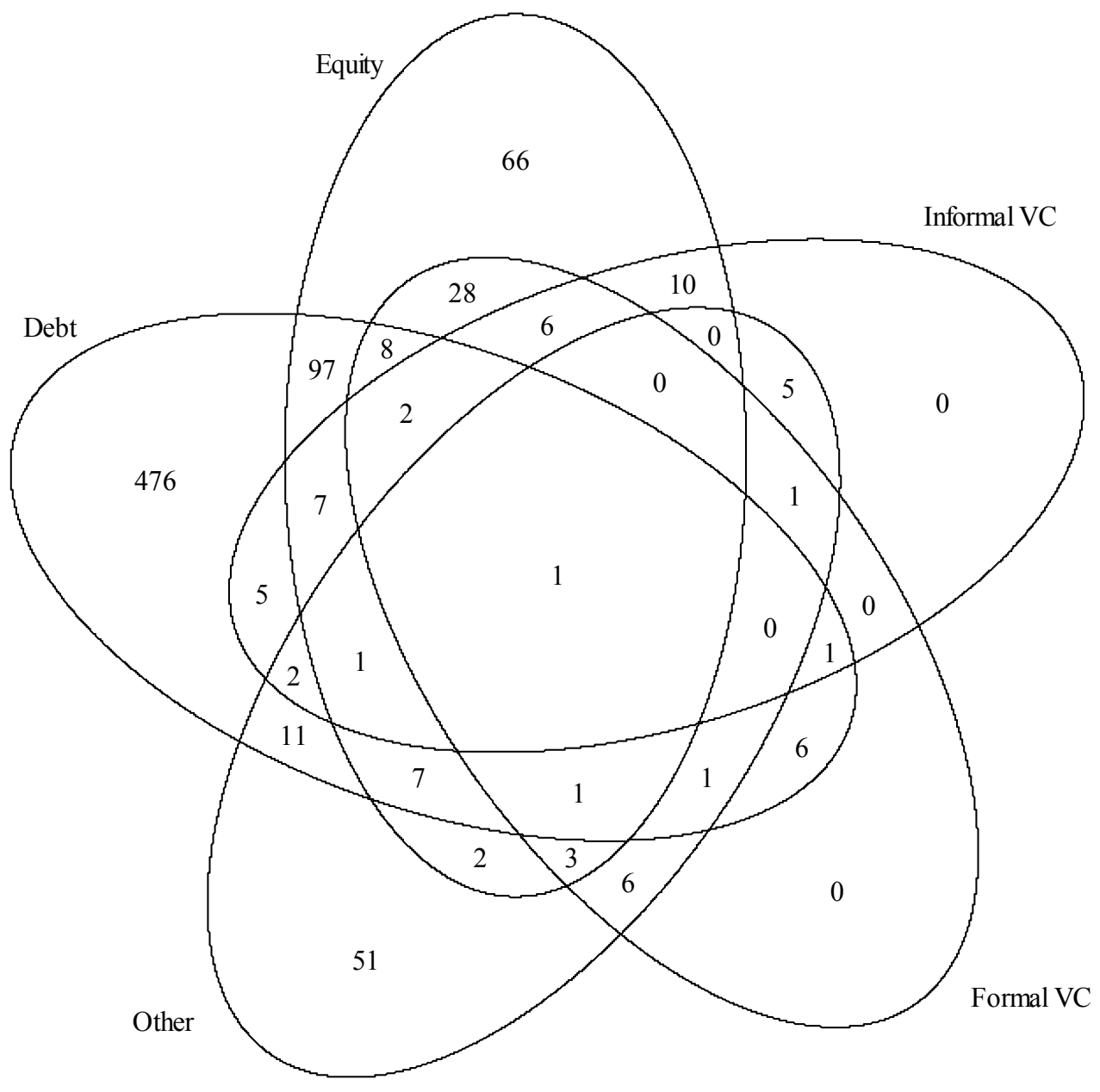


Table 1. Variable definitions

\begin{tabular}{|c|c|}
\hline Variable name & Definition \\
\hline Firm obtained equity & $\begin{array}{l}\text { The firm obtained financing in the form of equity. Specifically, the } \\
\text { questionnaire asks firms, "Of the amount obtained approximately what } \\
\text { percentage of the amount you obtained came from... \{equity, borrowing, } \\
\text { other, venture capital firms, informal venture capital (e.g. Business } \\
\text { Angel) }\} " \text {. }\end{array}$ \\
\hline Firm obtained debt & The firm obtained financing in the form of borrowing; dummy variable. \\
\hline Firm obtained other finance & The firm obtained financing in the form of other sources; dummy variable. \\
\hline Firm obtained formal VC & $\begin{array}{l}\text { The firm obtained financing in the form of formal venture capital; dummy } \\
\text { variable. }\end{array}$ \\
\hline Firm obtained informal VC & $\begin{array}{l}\text { The firm obtained financing in the form of informal venture capital (e.g., } \\
\text { business angels); dummy variable. }\end{array}$ \\
\hline Age $(\log )$ & The natural log of the number of years from incorporation until 2005 \\
\hline Size (Log(Employees)) & $\begin{array}{l}\text { The natural logarithm of the number of employees in the most recent } \\
\text { financial year }\end{array}$ \\
\hline US firm & The firm has its headquarters in the United States; dummy variable. \\
\hline Independent firm & $\begin{array}{l}\text { A dummy variable equal to one if the firm is independent (i.e., not a } \\
\text { subsidiary) }\end{array}$ \\
\hline Medium-high tech manuf. & $\begin{array}{l}\text { The firm is a medium-high tech manufacturing firm according to the OECD } \\
\text { (2005) Science, Technology and Industry Scoreboard. }\end{array}$ \\
\hline Medium-low tech manuf. & The firm is a medium-low tech manufacturing firm. \\
\hline R\&D services \& software & The firm is an R\&D service or software firm. \\
\hline Other services & The firm is a service firm other than R\&D or software. \\
\hline Other sector & The firm operates under a SIC code not covered above. \\
\hline Internationalization & $\begin{array}{l}\text { The number of world regions in which the firm does business; coded } \\
\text { numerically } 1=\text { national to } 7=\text { international }\end{array}$ \\
\hline Profit margin & $\begin{array}{l}\text { Pre-tax profits / turnover; both three years prior to the survey. Values } \\
\text { outside the interval }[-1,1] \text { are interpreted as data errors and replaced by } \\
\text { imputed values using random regression imputation. }\end{array}$ \\
\hline Competitors (Log) & $\begin{array}{l}\text { Number of companies that the firm regards as serious competitors plus one, } \\
\text { in logs. }\end{array}$ \\
\hline Growth ambition & Expected turnover in 10 years, coded $1=$ "A lot smaller" to $5=$ "A lot larger" \\
\hline CEO has a degree & The firm's Chief Executive or MD has a degree; dummy variable. \\
\hline Human capital staff & $\begin{array}{l}\text { Approximate number of workforce that have a university degree as a } \\
\text { percentage of the total number of employees }\end{array}$ \\
\hline R\&D expenditures / Turnover & Total R\&D expenditure / turnover three years prior to the survey \\
\hline Log (Number of patents) & The natural log of the firm's number of patents \\
\hline Product innovation & $\begin{array}{l}\text { The firm developed a novel manufacturing or service product innovation } \\
\text { that is new to the industry; dummy variable. }\end{array}$ \\
\hline Process innovation & $\begin{array}{l}\text { The firm developed a novel manufacturing or service process innovation } \\
\text { that is new to the industry; dummy variable. }\end{array}$ \\
\hline Breadth of IP protection & $\begin{array}{l}\text { Number of innovation protection methods used (registration of design, } \\
\text { trademarks, patents, confidentiality agreements, copyright, secrecy, } \\
\text { complexity of design and lead-time advantage on competitors) }\end{array}$ \\
\hline
\end{tabular}


Table 2. Descriptive statistics

This table shows descriptive statistics for the variables used in our analyses. Median and standard deviation are not shown for dummy variables.

\begin{tabular}{|c|c|c|c|c|c|c|c|}
\hline Variable name & $\mathrm{N}$ & Min & Max & Mean & Median & Std. Dev. & Imputed \\
\hline \multicolumn{8}{|l|}{ Dependent variables } \\
\hline Firm obtained equity & 812 & 0 & 1 & 0.299 & & & $0.0 \%$ \\
\hline Firm obtained debt & 827 & 0 & 1 & 0.780 & & & $0.0 \%$ \\
\hline Firm obtained other finance & 812 & 0 & 1 & 0.116 & & & $0.0 \%$ \\
\hline Firm obtained formal VC & 817 & 0 & 1 & 0.081 & & & $0.0 \%$ \\
\hline Firm obtained informal VC & 840 & 0 & 1 & 0.049 & & & $0.0 \%$ \\
\hline \multicolumn{8}{|l|}{ Innovation profile } \\
\hline R\&D expenditures / Turnover & 851 & 0 & 4.134 & 0.250 & 0.012 & 0.746 & $31.8 \%$ \\
\hline Log (Number of patents) & 851 & 0 & 4.220 & 0.382 & 0 & 0.795 & $1.5 \%$ \\
\hline Product innovation & 851 & 0 & 1 & 0.479 & & & $0.7 \%$ \\
\hline Process innovation & 851 & 0 & 1 & 0.334 & & & $1.1 \%$ \\
\hline Breadth of IP protection & 851 & 0 & 8 & 4.300 & 4 & 2.608 & $0.0 \%$ \\
\hline Human capital staff & 851 & 0 & 1 & 0.304 & 0.176 & 0.319 & $4.3 \%$ \\
\hline \multicolumn{8}{|l|}{ Control variables } \\
\hline Age $(\log )$ & 851 & 0.693 & 5.720 & 2.966 & 2.996 & 0.861 & $0.1 \%$ \\
\hline Size (Log(Employees)) & 851 & 0 & 7.679 & 3.746 & 3.662 & 1.170 & $27.0 \%$ \\
\hline US firm & 851 & 0 & 1 & 0.533 & & & $0.0 \%$ \\
\hline Independent firm & 851 & 0 & 1 & 0.890 & & & $0.0 \%$ \\
\hline Medium-high tech manuf. & 851 & 0 & 1 & 0.298 & & & $0.0 \%$ \\
\hline Medium-low tech manuf. & 851 & 0 & 1 & 0.401 & & & $0.0 \%$ \\
\hline R\&D services \& software & 851 & 0 & 1 & 0.114 & & & $0.0 \%$ \\
\hline Other services & 851 & 0 & 1 & 0.154 & & & $0.0 \%$ \\
\hline Other sector & 851 & 0 & 1 & 0.033 & & & $0.0 \%$ \\
\hline Internationalization & 851 & 1 & 7 & 2.421 & 2 & 1.509 & $20.0 \%$ \\
\hline Profit margin & 851 & -1 & 1 & 0.032 & 0.035 & 0.164 & $41.0 \%$ \\
\hline Competitors (Log) & 851 & 0 & 6.909 & 1.976 & 1.792 & 0.984 & $3.9 \%$ \\
\hline Growth ambition & 851 & 1 & 5 & 4.618 & 5 & 0.738 & $1.3 \%$ \\
\hline CEO has an MBA & 851 & 0 & 1 & 0.182 & 0 & 0.386 & $1.6 \%$ \\
\hline CEO has a PhD & 851 & 0 & 1 & 0.060 & 0.000 & 0.237 & $1.6 \%$ \\
\hline
\end{tabular}




\section{Table 3. Types of finance}

This table shows combinations of finance obtained by the firms in our sample. Firms are asked whether they obtained equity, debt or other finance. In addition, they are asked whether this funding was from venture capital firms or informal venture capital (e.g., business angels). A firm may, for example, simultaneously obtain equity and debt, part of which may come from venture capital firms. To test possible orderings of various combinations of these types of finance, we define three sets of mutually exclusive classes.

\begin{tabular}{|c|c|c|}
\hline Short name & $\mathrm{N}$ & Type of capital obtained by the firm \\
\hline \multicolumn{3}{|l|}{4 classes } \\
\hline $\mathrm{VC}$ & 96 & Formal or informal venture capital \\
\hline Equity/-VC & 172 & Equity, but no venture capital \\
\hline “Other” only & 51 & "Other" finance only: neither debt, equity nor venture capital \\
\hline Debt/-Equity\&-VC & 487 & Debt, but neither equity nor $\mathrm{VC}$ \\
\hline \multicolumn{3}{|l|}{6 classes } \\
\hline VC\&Equity & 44 & VC and neither debt nor "other" finance \\
\hline VC\&-Equity & 51 & VC and debt or "other" finance \\
\hline Equity only & 66 & Equity only, that is, equity but neither of debt, "other", VC \\
\hline “Other" only & 51 & "Other" finance only: neither debt, equity nor venture capital \\
\hline Other & 117 & $\begin{array}{l}\text { Other "other" finance (residual category): No VC or "other" finance, but equity } \\
\text { and debt OR: no VC but "other" finance and debt or equity }\end{array}$ \\
\hline Debt only & 476 & Debt only: debt but no equity, "other", or VC finance \\
\hline \multicolumn{3}{|l|}{8 classes } \\
\hline FVC\&Equity & 28 & Formal VC and equity, but no informal VC, debt or "other" finance \\
\hline IVC\&Equity & 16 & Informal VC, but no debt or "other" finance \\
\hline IVC\&-Equity & 25 & Informal VC and debt or "other" finance \\
\hline FVC\&-Equity & 25 & Formal VC and no informal VC and (debt or "other" finance) \\
\hline Equity only & 66 & Equity only: No debt, "other" or VC finance \\
\hline “Other” only & 51 & "Other" finance only: neither debt, equity nor venture capital \\
\hline Other & 117 & $\begin{array}{l}\text { Other "other" finance (residual category): No VC or "other" finance, but equity } \\
\text { and debt OR: no VC but "other" finance and debt or equity }\end{array}$ \\
\hline Debt only & 476 & Debt only: debt but no equity, “other”, or VC finance \\
\hline
\end{tabular}


Table 4. Correlation matrix

Pearson correlation coefficients for pairwise complete observations, significance levels: $* * * \mathrm{p}<0.01 ; * * \mathrm{p}<0.05 ; * \mathrm{p}<0.1$.

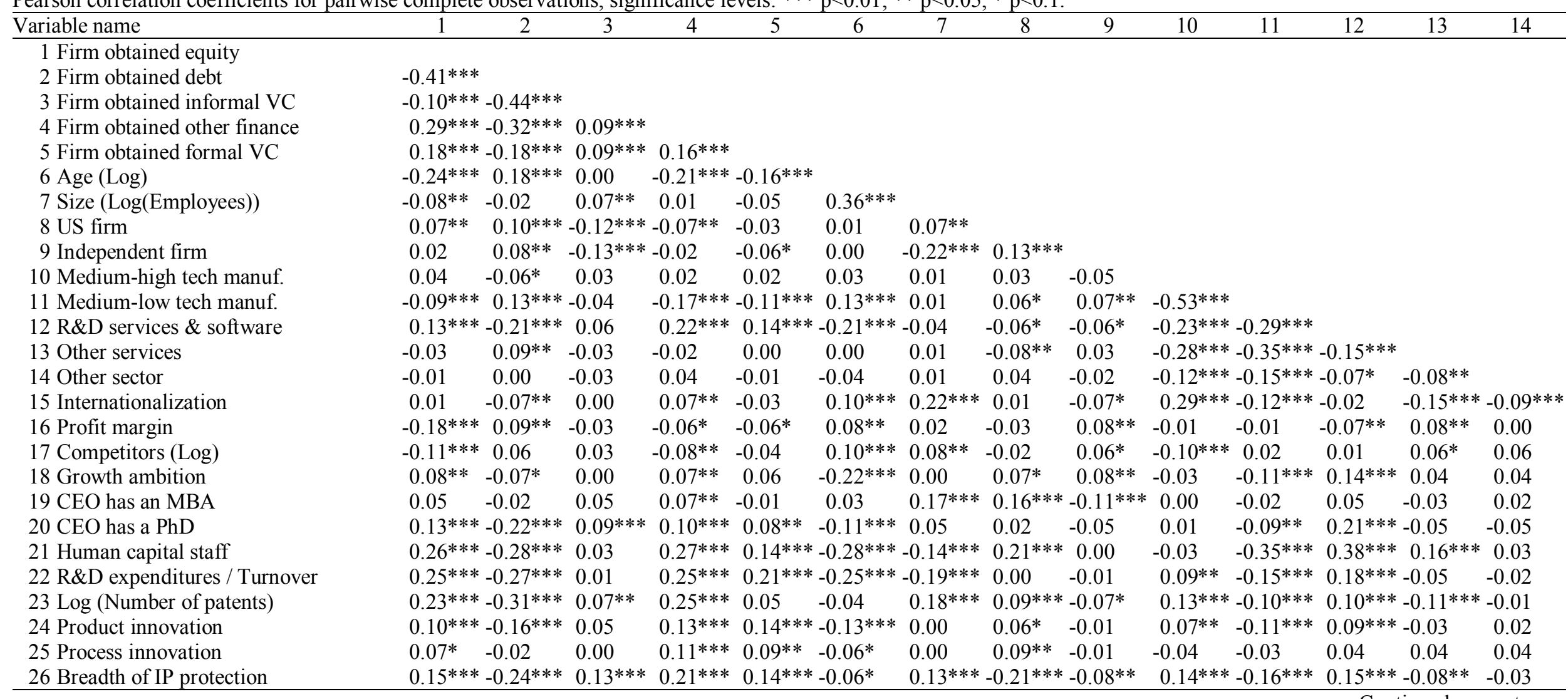

Continued on next page 
Table 4. Correlation matrix (continued)

\begin{tabular}{|c|c|c|c|c|c|c|c|c|c|c|c|}
\hline & 15 & 16 & 17 & 18 & 19 & 20 & 21 & 22 & 23 & 24 & 25 \\
\hline 16 Profit margin & $-0.07 * *$ & & & & & & & & & & \\
\hline 17 Competitors (Log) & $-0.13 * * *$ & 0.01 & & & & & & & & & \\
\hline 18 Growth ambition & $0.09 * * *$ & -0.05 & -0.04 & & & & & & & & \\
\hline $19 \mathrm{CEO}$ has an MBA & 0.05 & 0.01 & -0.04 & 0.03 & & & & & & & \\
\hline 20 CEO has a PhD & 0.05 & 0.03 & -0.04 & 0.03 & -0.06 & & & & & & \\
\hline 21 Human capital staff & 0.04 & $-0.07 *$ & -0.01 & $0.18 * * *$ & $0.10 * * *$ & $0.22 * * *$ & & & & & \\
\hline 22 R\&D expenditures / Turnover & 0.05 & $-0.10 * * *$ & $-0.08 * *$ & $0.09 * * *$ & 0.00 & $0.18^{* * *}$ & $0.33 * * *$ & & & & \\
\hline $23 \log$ (Number of patents) & $0.24 * * *$ & $-0.11 * * *$ & $-0.09 * * *$ & $0.07 *$ & $0.07 * *$ & $0.29 * * *$ & $0.29 * * *$ & $0.30 * * *$ & & & \\
\hline 24 Product innovation & $0.20 * * *$ & -0.01 & $-0.10 * * *$ & $0.15^{* * *}$ & 0.03 & $0.07 * *$ & $0.18 * * *$ & $0.14 * * *$ & $0.24 * * *$ & & \\
\hline 25 Process innovation & 0.00 & -0.01 & -0.01 & $0.07 * *$ & -0.02 & $0.06^{*}$ & $0.06^{*}$ & $0.10 * * *$ & $0.12 * * *$ & $0.31 * * *$ & \\
\hline 26 Breadth of IP protection & $0.31 * * *$ & $-0.10 * * *$ & $-0.06 *$ & $0.11 * * *$ & $0.07 * *$ & $0.12 * * *$ & $0.17 * * *$ & $0.21 * * *$ & $0.40 * * *$ & $0.36 * * *$ & $0.11 * * *$ \\
\hline
\end{tabular}


Table 5. Type of finance obtained - Probit models

This table shows results for probit models for the likelihood of obtaining specific types of capital. We use dummy variables equal to one if the firm obtains any amount of equity, debt or venture capital. Standard errors are in parentheses. Significance levels: *** $\mathrm{p}<0.01 ; * * \mathrm{p}<0.05 ; * \mathrm{p}<0.1$.

\begin{tabular}{|c|c|c|c|c|c|}
\hline & $\begin{array}{c}(1) \\
\text { Any Debt }\end{array}$ & $\begin{array}{c}\text { (2) } \\
\text { Any Equity }\end{array}$ & $\begin{array}{c}(3) \\
\text { Any VC }\end{array}$ & $\begin{array}{c}(4) \\
\text { Any Formal VC }\end{array}$ & $\begin{array}{c}(5) \\
\text { Any Informal VC }\end{array}$ \\
\hline R\&D expenditures / Turnover & $-0.185(0.07)^{* *}$ & $0.189(0.07)^{* *}$ & $0.182(0.08)^{* *}$ & $0.141(0.08)^{*}$ & $0.198(0.09)^{* *}$ \\
\hline Log (Number of patents) & $-0.251(0.08)^{* * *}$ & $0.161(0.08)^{* *}$ & $0.070(0.09)$ & $0.172(0.09)^{*}$ & $-0.209(0.12)^{*}$ \\
\hline Product innovation & $-0.233(0.12)^{*}$ & $-0.043(0.11)$ & $0.142(0.16)$ & $-0.039(0.18)$ & $0.400(0.20)^{* *}$ \\
\hline Process innovation & $0.144(0.12)$ & $0.080(0.11)$ & $0.320(0.14)^{* *}$ & $0.335(0.16)^{* *}$ & $0.202(0.18)$ \\
\hline Breadth of IP protection & $-0.016(0.03)$ & $0.023(0.02)$ & $0.100(0.03)^{* * *}$ & $0.073(0.04)^{*}$ & $0.095(0.04)^{* *}$ \\
\hline Human capital staff & $-0.846(0.21)^{* * *}$ & $0.567(0.20)^{* * *}$ & $0.582(0.25)^{* *}$ & $0.795(0.27)^{* * *}$ & $0.199(0.31)$ \\
\hline \multicolumn{6}{|l|}{ Control variables } \\
\hline Age (Log) & $0.150(0.07)^{* *}$ & $-0.260(0.07)^{* * *}$ & $-0.329(0.09)^{* * *}$ & $-0.359(0.11)^{* * *}$ & $-0.217(0.12)^{*}$ \\
\hline Size (Log(Employees)) & $-0.116(0.05)^{* *}$ & $0.036(0.05)$ & $0.222(0.07)^{* * *}$ & $0.245(0.08)^{* * *}$ & $0.077(0.09)$ \\
\hline US firm & $0.555(0.13)^{* * *}$ & $0.074(0.11)$ & $-0.344(0.16)^{* *}$ & $-0.502(0.18)^{* * *}$ & $-0.033(0.20)$ \\
\hline Independent firm & $0.038(0.17)$ & $0.330(0.18)^{*}$ & $0.265(0.22)$ & $0.464(0.26)^{*}$ & $-0.206(0.25)$ \\
\hline Medium-high tech manuf. & $-0.103(0.31)$ & $0.178(0.29)$ & $-0.113(0.36)$ & $-0.316(0.40)$ & $0.460(0.54)$ \\
\hline Medium-low tech manuf. & $-0.023(0.30)$ & $0.092(0.28)$ & $-0.489(0.36)$ & $-0.601(0.40)$ & $0.129(0.55)$ \\
\hline R\&D services \& software & $-0.164(0.33)$ & $0.103(0.31)$ & $0.197(0.37)$ & $0.037(0.40)$ & $0.550(0.54)$ \\
\hline Other services & $0.348(0.32)$ & $0.073(0.30)$ & $-0.359(0.37)$ & $-0.354(0.41)$ & $0.230(0.55)$ \\
\hline Profit margin & $0.322(0.32)$ & $-1.251(0.32)^{* * *}$ & $-0.111(0.38)$ & $0.023(0.43)$ & $-0.336(0.46)$ \\
\hline Competitors (Log) & $0.028(0.06)$ & $-0.112(0.05)^{* *}$ & $-0.122(0.08)$ & $-0.122(0.09)$ & $-0.072(0.09)$ \\
\hline Growth ambition & $0.035(0.08)$ & $-0.032(0.07)$ & $-0.073(0.11)$ & $-0.089(0.13)$ & $-0.007(0.14)$ \\
\hline CEO has an MBA & $-0.036(0.14)$ & $0.141(0.13)$ & $0.135(0.17)$ & $0.286(0.19)$ & $-0.094(0.23)$ \\
\hline CEO has a PhD & $-0.456(0.23)^{* *}$ & $0.227(0.22)$ & $0.007(0.25)$ & $-0.185(0.28)$ & $0.257(0.30)$ \\
\hline Internationalization & $0.038(0.04)$ & $-0.056(0.04)$ & $-0.063(0.05)$ & $0.018(0.05)$ & $-0.142(0.07)^{* *}$ \\
\hline Intercept & $0.791(0.57)$ & $-0.266(0.53)$ & $-1.309(0.75)^{*}$ & $-1.616(0.86)^{*}$ & $-1.861(1.00)^{*}$ \\
\hline \multicolumn{6}{|l|}{ Model statistics } \\
\hline Chi-Sq. test p-value & 0.000 & 0.000 & 0.000 & 0.000 & 0.000 \\
\hline McFadden pseudo-R ${ }^{2}$ (adj.) & 0.146 & 0.096 & 0.198 & 0.198 & 0.071 \\
\hline Observations & 827 & 812 & 814 & 817 & 840 \\
\hline Log-Likelihood & -352.130 & -427.720 & -216.924 & -163.951 & -132.241 \\
\hline
\end{tabular}


Table 6. Type of finance obtained - Multinomial logit models

This table shows results for a multinomial logit models for the likelihood of obtaining specific types of capital. We use dummy variables equal to one if the majority of finance is obtained from equity, debt or other sources in model 1 and formal venture capital, informal venture capital and other sources in model 2. Standard errors are in parentheses. Significance levels: *** $\mathrm{p}<0.01 ; * * \mathrm{p}<0.05 ; * \mathrm{p}<0.1$.

Equity \& Debt (1)

Majority of finance obtained from ... compared to "Equity"

\section{R\&D expenditures / Turnover}

Log (Number of patents)

Product innovation

Process innovation

Breadth of IP protection

Human capital staff

Control variables

Age (Log)

Size (Log(Employees))

US firm

Independent firm

Medium-high tech manuf.

Medium-low tech manuf.

R\&D services \& software

Other services

Profit margin

Competitors (Log)

Growth ambition

CEO has an MBA

CEO has a $\mathrm{PhD}$

Internationalization

Intercept

Model statistics

LR-test p-value

McFadden pseudo-R ${ }^{2}$ (adj.)

Observations

Log-Likelihood
Venture Capital (2)

Majority of finance obtained from ... compared to "Other"

Formal Venture Capital Informal Venture Capital

$-0.177(0.19)$

$0.289(0.20)$

$0.123(0.34)$

$-0.134(0.33)$

$0.037(0.07)$

$-0.649(0.56)$

$0.465(0.20)^{* *}$

$0.064(0.15)$

$-0.795(0.35)^{* *}$

$-1.179(0.45)^{* * *}$

$0.270(0.90)$

$0.289(0.89)$

$-0.039(0.94)$

$0.098(0.96)$

$1.413(0.88)$

$0.270(0.16)^{*}$

$0.165(0.21)$

$0.303(0.39)$

$0.792(0.51)$

$-0.062(0.11)$

$-2.074(1.59)$

$\begin{array}{lc}0.359(0.16)^{* *} & 0.504(0.20)^{* *} \\ 0.306(0.20) & -0.563(0.32)^{*} \\ 0.301(0.42) & 0.719(0.53) \\ 0.634(0.35)^{*} & 0.437(0.45) \\ 0.085(0.09) & 0.166(0.11) \\ 1.228(0.59)^{* *} & 0.815(0.76)\end{array}$

$-0.864(0.24) * * *$

$-0.513(0.30)^{*}$

$0.434(0.22)^{* *}$

$-0.855(0.51)^{*}$

$0.258(0.63)$

$1.302(0.76)^{*}$

$0.234(0.84)$

$1.600(0.74)^{* *}$

$-1.586(0.72)^{* *}$

$0.544(0.49)$

$0.519(1.12)$

$0.194(0.87)$

$-0.159(0.20)$

$0.297(0.41)$

$0.748(0.43)^{*}$

$0.261(0.55)$

$0.001(0.12)$

$-5.034(2.35)^{* *}$

$079(0.24)$

$0.009(0.35)$

$0.517(0.53)$

$1.083(0.65)^{*}$

$-0.315(0.18)^{*}$

$-5.348(2.35)^{* *}$

$\begin{array}{ll}0.000 & 0.000\end{array}$

$\begin{array}{ll}0.113 & 0.169\end{array}$

813

$-217.362$ 
Table 7. Pecking order - Ordered probit models

This table present results for ordered probit models of hypothesized orderings of 4,6 and 8 classes of financing. Class definitions are provided in Table 3. For example, "VC | Equity/-VC" marks the class boundary between the class containing venture capital and the class containing equity that is not venture capital. The class "VC" includes both formal and informal VC in models 1 and 2, while VC is split into formal and informal VC in models 3 and 4. Models 1-3 test pecking orders implied by pecking order theory, while model 4 shows the best fit among all possible permutations of 8 unordered classes. Standard errors are in parentheses. Significance levels: $* * * p<0.01$; $* * \mathrm{p}<0.05 ; * \mathrm{p}<0.1$.

\begin{tabular}{|c|c|c|c|c|}
\hline & $\begin{array}{c}(1) \\
4 \text { classes } \\
\text { (a-priori order) }\end{array}$ & $\begin{array}{c}(2) \\
6 \text { classes } \\
\text { (a-priori order) } \\
\end{array}$ & $\begin{array}{c}(3) \\
8 \text { classes } \\
\text { (a-priori order) }\end{array}$ & $\begin{array}{c}(4) \\
8 \text { classes } \\
\text { (max. likelihood) }\end{array}$ \\
\hline \multicolumn{5}{|l|}{ Class intercepts } \\
\hline VC | Equity/-VC & $-0.910(0.47)^{*}$ & & & \\
\hline Equity/-VC | "Other" only & $0.016(0.47)$ & & & \\
\hline "Other" only | Debt/-Equity\&-VC & $0.214(0.47)$ & & & \\
\hline $\begin{array}{l}\text { VC\&Equity | VC\&-Equity } \\
\text { VC\&-Eequity | Equity only } \\
\text { Equity only | "Other" only } \\
\text { "Other" only | Other } \\
\text { Other | Debt only }\end{array}$ & & $\begin{array}{l}-1.654(0.46)^{* * *} \\
-1.100(0.46)^{* *} \\
-0.649(0.46) \\
-0.382(0.45) \\
0.099(0.45)\end{array}$ & & \\
\hline $\begin{array}{l}\text { FVC\&Equity | IVC.E } \\
\text { IVC\&Equity | IVC\&-Equity } \\
\text { IVC\&-Equity | FVC\&-Equity } \\
\text { IVC\&-Equity | FVC\&Equity } \\
\text { FVC\&Equity | FVC\&-Equity } \\
\text { FVC\&-Equity | Equity only } \\
\text { Equity only | "Other" only } \\
\text { "Other" only | Other } \\
\text { Other | Debt only }\end{array}$ & & & $\begin{array}{l}-1.810(0.46)^{* * *} \\
-1.480(0.46)^{* * *} \\
-1.249(0.46)^{* * *} \\
-0.798(0.46)^{*} \\
-0.533(0.46) \\
-0.054(0.46)\end{array}$ & $\begin{array}{l}-1.148(0.46)^{* *} \\
-0.694(0.46) \\
-0.427(0.46) \\
0.055(0.46)\end{array}$ \\
\hline \multicolumn{5}{|l|}{ Innovation profile } \\
\hline R\&D expenditures / Turnover & $-0.171(0.06)^{* * *}$ & $-0.192(0.06) * * *$ & $-0.181(0.06)^{* * *}$ & $-0.187(0.06)^{* * *}$ \\
\hline Log (Number of patents) & $-0.152(0.07)^{* *}$ & $-0.159(0.06)^{* *}$ & $-0.116(0.06)^{*}$ & $-0.175(0.06)^{* * *}$ \\
\hline Product innovation & $-0.038(0.10)$ & $-0.100(0.10)$ & $-0.119(0.10)$ & $-0.092(0.10)$ \\
\hline Process innovation & $-0.078(0.10)$ & $-0.041(0.09)$ & $-0.023(0.09)$ & $-0.050(0.09)$ \\
\hline Breadth of IP protection & $-0.048(0.02)^{* *}$ & $-0.043(0.02)^{* *}$ & $-0.048(0.02)^{* *}$ & $-0.044(0.02)^{* *}$ \\
\hline Human capital staff & $-0.588(0.17)^{* * *}$ & $-0.695(0.17)^{* * *}$ & $-0.618(0.17)^{* * *}$ & $-0.667(0.17)^{* * *}$ \\
\hline \multicolumn{5}{|l|}{ Control variables } \\
\hline Age $(\log )$ & $0.282(0.06)^{* * *}$ & $0.261(0.06)^{* * *}$ & $0.251(0.06)^{* * *}$ & $0.253(0.06)^{* * *}$ \\
\hline Size (Log(Employees)) & $-0.121(0.05)^{* * *}$ & $-0.133(0.04) * * *$ & $-0.133(0.04)^{* * *}$ & $-0.124(0.04) * * *$ \\
\hline US firm & $0.199(0.10)^{*}$ & $0.308(0.10)^{* * *}$ & $0.267(0.10)^{* * *}$ & $0.311(0.10)^{* * *}$ \\
\hline Independent firm & $-0.137(0.15)$ & $-0.090(0.14)$ & $-0.039(0.14)$ & $-0.095(0.14)$ \\
\hline Medium-high tech manuf. & $-0.039(0.25)$ & $-0.063(0.25)$ & $-0.174(0.24)$ & $-0.013(0.24)$ \\
\hline Medium-low tech manuf. & $0.134(0.25)$ & $0.091(0.24)$ & $-0.009(0.24)$ & $0.124(0.24)$ \\
\hline R\&D services \& software & $-0.134(0.27)$ & $-0.195(0.26)$ & $-0.256(0.26)$ & $-0.176(0.26)$ \\
\hline Other services & $0.210(0.26)$ & $0.268(0.25)$ & $0.144(0.25)$ & $0.290(0.25)$ \\
\hline Profit margin & $0.927(0.27)^{* * *}$ & $0.692(0.26)^{* * *}$ & $0.729(0.25)^{* * *}$ & $0.716(0.26)^{* * *}$ \\
\hline Competitors (Log) & $0.079(0.05)^{*}$ & $0.068(0.05)$ & $0.061(0.05)$ & $0.064(0.05)$ \\
\hline Growth ambition & $0.052(0.06)$ & $0.041(0.06)$ & $0.022(0.06)$ & $0.023(0.06)$ \\
\hline $\mathrm{CEO}$ has an $\mathrm{MBA}$ & $-0.135(0.12)$ & $-0.107(0.11)$ & $-0.076(0.11)$ & $-0.125(0.11)$ \\
\hline CEO has a PhD & $-0.187(0.19)$ & $-0.242(0.19)$ & $-0.260(0.18)$ & $-0.229(0.18)$ \\
\hline Internationalization & $0.080(0.03)^{* *}$ & $0.071(0.03)^{* *}$ & $0.086(0.03)^{* * *}$ & $0.074(0.03)^{* *}$ \\
\hline \multicolumn{5}{|l|}{ Model statistics } \\
\hline Chi-sq. test p-value & 0.000 & 0.000 & 0.000 & 0.000 \\
\hline McFadden pseudo-R ${ }^{2}$ (adj.) & 0.086 & 0.082 & 0.067 & 0.076 \\
\hline Observations & 806 & 805 & 804 & 804 \\
\hline Log-Likelihood & -759.032 & -939.272 & -1009.854 & -999.374 \\
\hline
\end{tabular}


Table 8. Pecking order - Sample split by country

This table present results for ordered probit models of hypothesized orderings of 4 classes of financing. Model 1 is estimated using the subsample of UK firms, while model 2 uses US firms. Class definitions are provided in Table 3. For example, "VC | Equity/-VC" marks the class boundary between the class containing venture capital and the class containing equity that is not venture capital. Standard errors are in parentheses. Significance levels: *** $\mathrm{p}<0.01 ; * * \mathrm{p}<0.05$; * $\mathrm{p}<0.1$.

\begin{tabular}{|c|c|c|c|c|}
\hline & \multicolumn{2}{|c|}{$(1)$} & \multicolumn{2}{|c|}{$(2)$} \\
\hline Class intercepts & & & & \\
\hline VC | Equity\&-VC & -1.534 & $(0.68)^{* *}$ & -0.264 & $(0.69)$ \\
\hline Equity\&-VC |"Other" only & -0.799 & $(0.68)$ & 0.896 & $(0.69)$ \\
\hline "Other" only $\mid$ Debt/-Equity\&-VC & -0.494 & $(0.68)$ & 1.015 & $(0.69)$ \\
\hline \multicolumn{5}{|l|}{ Innovation profile } \\
\hline R\&D expenditures / Turnover & -0.116 & $(0.09)$ & -0.201 & $(0.09)^{* *}$ \\
\hline Log (Number of patents) & -0.027 & $(0.11)$ & -0.196 & $(0.09)^{* *}$ \\
\hline Product innovation & -0.145 & $(0.15)$ & 0.064 & $(0.14)$ \\
\hline Process innovation & -0.229 & $(0.15)$ & 0.022 & $(0.13)$ \\
\hline Breadth of IP protection & -0.037 & $(0.03)$ & -0.071 & $(0.04)^{*}$ \\
\hline Human capital staff & -0.845 & $(0.27)^{* * *}$ & -0.371 & $(0.24)$ \\
\hline \multicolumn{5}{|l|}{ Control variables } \\
\hline Age $(\log )$ & 0.106 & $(0.08)$ & 0.501 & $(0.10) * * *$ \\
\hline Size (Log(Employees)) & -0.141 & $(0.07)^{* *}$ & -0.123 & $(0.06)^{*}$ \\
\hline \multicolumn{5}{|l|}{ US firm } \\
\hline Independent firm & -0.198 & $(0.20)$ & -0.145 & $(0.23)$ \\
\hline Medium-high tech manuf. & 0.078 & $(0.43)$ & -0.122 & $(0.33)$ \\
\hline Medium-low tech manuf. & 0.529 & $(0.42)$ & -0.069 & $(0.32)$ \\
\hline R\&D services \& software & 0.012 & $(0.44)$ & -0.184 & $(0.37)$ \\
\hline Other services & 0.352 & $(0.43)$ & 0.303 & $(0.36)$ \\
\hline Profit margin & 1.165 & $(0.41)^{* * *}$ & 0.761 & $(0.38)^{* *}$ \\
\hline Competitors (Log) & 0.047 & $(0.07)$ & 0.105 & $(0.07)$ \\
\hline Growth ambition & 0.010 & $(0.09)$ & 0.130 & $(0.09)$ \\
\hline $\mathrm{CEO}$ has an MBA & -0.089 & $(0.21)$ & -0.165 & $(0.14)$ \\
\hline CEO has a PhD & -0.291 & $(0.30)$ & -0.036 & $(0.27)$ \\
\hline Internationalization & 0.090 & $(0.05)^{*}$ & 0.081 & $(0.05)^{*}$ \\
\hline \multicolumn{5}{|l|}{ Model statistics } \\
\hline Chi-sq. test p-value & 0.000 & & 0.000 & \\
\hline McFadden pseudo-R ${ }^{2}$ (adj.) & 0.055 & & 0.099 & \\
\hline Observations & 362 & & 444 & \\
\hline Log-Likelihood & -360.925 & & -375.185 & \\
\hline
\end{tabular}

